\title{
SULF2 Gene
}

National Cancer Institute

\section{Source}

National Cancer Institute. SULF2 Gene. NCI Thesaurus. Code C105088.

This gene plays a role in heparan sulfate metabolism. 